\title{
Perinatal morbidity and mortality of children born to mothers with chronic kidney disease
}

\author{
Ma. Juana Pérez-López, ${ }^{1}$ Isabel G. Leyva-Reséndiz, ${ }^{2}$ Benjamín Vázquez-Vega, ${ }^{1}$ \\ Ernesto L. Chávez-López, ${ }^{1}$ Juan C. Hernández-Rivera ${ }^{3 *}$ and José R. Paniagua-Sierra ${ }^{3}$ \\ ${ }^{1}$ Specialty Hospital, Centro Médico Nacional La Raza; ${ }^{2}$ Gynecology and Obstetrics Hospital, Centro Médico Nacional La Raza; ${ }^{3}$ Specialty Hospital, \\ Centro Médico Nacional Siglo XXI. Instituto Mexicano del Seguro Social, Mexico City, Mexico
}

\begin{abstract}
Introduction: Chronic kidney disease (CKD) associated with pregnancy increases the risk of maternal and fetal complications. Objective: To determine perinatal morbidity and mortality of children born to mothers with mild and moderate CKD during pregnancy. Methods: Retrospective study of medical records of women with mild and moderate CKD during pregnancy cared for at La Raza National Medical Center between 2010 and 2016. Results: There were 142 patients, 99 (69.72\%) with mild CKD and 43 (30.28\%) with moderate CKD; 79 neonates (55.63\%) reached full term, 28 (19.71\%) had growth restriction; 44 (30.98\%), low birth weight and 54 (38.02\%) were admitted to the neonatal intensive care unit (NICU); and four women (4.04\%) had an abortion; in four (2.81\%), their children had intrauterine death, and in 10 (7.04\%), neonatal death. High blood pressure (odds ratio $[O R]=6.93)$ and hemoglobin $<11 \mathrm{~g} / \mathrm{dL}(O R=2.48)$ were risk factors for prematurity. Conclusion: A relationship was found between anemia and blood pressure levels and risk for prematurity, low Apgar, and NICU admission.
\end{abstract}

KEY WORDS: Mild kidney disease. Moderate kidney disease. Pregnancy. Perinatal mortality.

\section{Morbilidad y mortalidad perinatal de hijos de mujeres con enfermedad renal crónica}

\section{Resumen}

Introducción: La enfermedad renal (ER) crónica asociada al embarazo incrementa el riesgo de complicaciones maternas y fetales. Objetivo: Determinar la morbilidad y mortalidad perinatal del hijo de madre con enfermedad renal leve y moderada del embarazo. Métodos: Estudio retrospectivo de expedientes de mujeres con ER leve y moderada del embarazo atendidas en el Centro Médico Nacional La Raza entre 2010 y 2016. Resultados: Se trató de 142 pacientes, 99 (69.72 \%) con ER leve y $43(30.28 \%)$ con ER moderada; 79 (55.63\%) neonatos llegaron a término, 28 (19.71\%) presentaron restricción de crecimiento; 44 (30.98\%), peso bajo al nacimiento y 54 (38.02\%) ingresaron a la unidad de cuidados intensivos neonatales; cuatro (4.04\%) mujeres presentaron aborto, en cuatro (2.81\%) sus hijos presentaron muerte intrauterina y en 10 (7.04\%), muerte neonatal. La presión arterial alta $(R M=6.93)$ y la hemoglobina $<11 \mathrm{~g} / \mathrm{dL}(R M=2.48)$ constituyeron factores de riesgo para prematurez. Conclusión: Se encontró relación entre la anemia y las cifras de tensión arterial como riesgo para prematurez, Apgar bajo e ingreso a unidad de cuidados intensivos neonatales.

PALABRAS CLAVE: Enfermedad renal leve. Enfermedad renal moderada. Embarazo. Mortalidad perinatal.

\footnotetext{
Correspondence:

Date of reception: 17-09-2020

*Juan C. Hernández-Rivera Date of acceptance: 29-09-2020

E-mail: juancarloshhernandezrivera@ hotmail.com

DOI: $10.24875 / G M M . M 21000575$

Gac Med Mex. 2021;157:356-363

Contents available at PubMed

0016-3813/0 2021 Academia Nacional de Medicina de México, A.C. Published by Permanye. This is an open acc license (http://creativecommons.org/licenses/by-nc-nd/4.0/).
} 


\section{Introduction}

The incidence of chronic kidney disease (KD) associated with pregnancy is approximately 0.03 to $0.12 \%$ according to registries in the North American population and $0.33 \%$ according to a Mexican study ${ }^{1,2}$. This association increases the risk of maternal and fetal complications. The most common fetal complications are intrauterine growth restriction (IUGR), low birth weight, longer hospital stay and perinatal death ${ }^{1-3}$.

Serum creatinine remains the gold standard for evaluating kidney function in pregnant women. The Davison-Lindheimer classification in pregnancy divides pregnant women with $\mathrm{KD}$ into three categories according to serum creatinine levels:

- With mild KD, creatinine $<1.4 \mathrm{mg} / \mathrm{mL}$.

- With moderate KD, creatinine between 1.4 and $2.8 \mathrm{mg} / \mathrm{dL}$.

- With severe $\mathrm{KD}$, creatinine $>2.8 \mathrm{mg} / \mathrm{dL}^{4,5}$.

The effects of KD on pregnancy include an increase in adverse fetal outcomes, which is correlated with $\mathrm{KD}$ severity before pregnancy ${ }^{6,7}$. In a study of 38 pregnant women with $\mathrm{KD}$, Bar et al. described prematurity in $22 \%$ and IUGR in $13 \%$, . In 67 patients with glomerular filtration $<60 \mathrm{~mL} /$ minute $/ 1.73 \mathrm{~m}^{2}$, Jones and Hayslett found prematurity and IUGR in $59 \%$, as well as fetal survival in $93 \% \%^{10-12}$. In a meta-analysis, Nevis et al. identified poorer fetal outcomes in women with $\mathrm{KD}$ with regard to those without this condition, such as premature birth, short length for gestational age and low birth weight, with odds ratios (ORs) of 1.8, 2.67 and 4.85, respectively ${ }^{13,14}$. Fetal and neonatal survival is lower when blood pressure levels are uncontrolled, with and without proteinuria (>500 mg/ day), as reported by Lindheimer and Katz ${ }^{15-23}$.

The purpose of the present study was to determine perinatal morbidity and mortality of newborns of women with mild and moderate KD of pregnancy.

\section{Methods}

A retrospective cohort of 142 neonates born to women with mild and moderate chronic KD, cared for between January 1, 2010, and December 31, 2016, at La Raza National Medical Center was analyzed; based on serum creatinine, they were stratified according to Davison-Lindheimer classification (Appendix 1).

Demographic and clinical data were obtained from medical records. Of the women, the week of pregnancy diagnosis, comorbidities and KD evolution time were captured. Newborns had decreased intrauterine growth (below $3^{\text {rd }}$ percentile), low birth weight $(<2500 \mathrm{~g})$, stillbirth and admission to the neonatal intensive care unit (NICU) recorded.

Data are expressed as frequencies, medians, and interquartile ranges or means \pm standard deviations according to the variables' characteristics. The differences between groups were analyzed with the chi-square test or Student's t-test, as appropriate. To establish risks, binary and multiple logistic regression calculation was performed. The Statistical Package for the Social Sciences program, version 25, was used.

\section{Results}

Between January 2010 and December 2016, 142 neonates born to women with mild and moderate chronic KD of pregnancy were registered. The group of neonates born to women with mild KD was made up of 99 subjects $(69.72 \%)$ and that of neonates born to women with moderate $K D$, of $43(30.28 \%)$.

Pregnant women baseline characteristics that influenced on fetal outcomes are described in table 1. Mean age was 29.2 years, with a minimum of 18 and a maximum of 44 ; the proportion of patients with comorbidities was $57.57 \%$ in the group with mild KD and $55.81 \%$ in the group with moderate KD. Maternal and fetal indications for pregnancy resolution are shown in table 2.

The main indication for pregnancy termination was pre-eclampsia with data consistent with severity, the second was chronic KD and the third differed in both groups: in patients with mild KD, it was labor active phase $(n=8,8.08 \%)$, and in the group with moderate $K D$, renal function deterioration $(n=7,16.27 \%)$. Cesarean section was the most used modality for terminating pregnancy.

Gestational age was calculated using the Capurro method: median of 35.31 weeks in the group of women with mild KD and 34.39 weeks in the group with moderate KD. Average weight of the newborns of women with mild KD was $2423 \mathrm{~g}$ and $2140 \mathrm{~g}$ in the children of women with moderate KD. Weight was adjusted by percentile according to gestational age, given the direct relationship between both characteristics (Appendix 2).

Full-term was reached in $55.63 \%$ of pregnancies, $35.91 \%$ of the children were premature (from 28.1 to 36.6 weeks of gestation) and $4.92 \%$ ( $<28.1$ weeks), extremely premature. IUGR occurred in $19.71 \%$, low weight for gestational age in $30.88 \%$, Apgar indicative of moderate depression in $3.52 \%$, Apgar indicative of 
Table 1. Baseline characteristics of women during pregnancy

\begin{tabular}{|c|c|c|c|c|c|}
\hline \multirow[t]{2}{*}{ Characteristics } & \multicolumn{2}{|c|}{ Mild KD ( $n=99)$} & \multicolumn{2}{|c|}{ Moderate KD $(n=43)$} & \multirow[t]{2}{*}{$p^{*}$} \\
\hline & Median & Min, Max & Median & Min, Max & \\
\hline Age (years) & 29.45 & 18,44 & 28.65 & 18,40 & 0.664 \\
\hline Gestations & 2.07 & 1,5 & 1.93 & 1,4 & 0.513 \\
\hline Deliveries & 0.33 & 0,2 & 0.37 & 0,2 & 0.682 \\
\hline Abortions & 0.38 & 0,2 & 0.34 & 0,2 & 0.945 \\
\hline Cesarean sections & 1.32 & 0,3 & 1.11 & 0,3 & 0.164 \\
\hline Hemoglobin (g/dL) & 11.97 & $9.3,16.8$ & 11.40 & $9,16.5$ & 0.450 \\
\hline Albumin (mg/dL) & 3.14 & $1.8,6.6$ & 3.01 & $1.4,4.7$ & 0.380 \\
\hline Creatinine (mg/dL) & 0.95 & $0.5,1.5$ & 1.84 & $1.4,2.7$ & $<0.001$ \\
\hline Urea (mg/dL) & 29.75 & $11,107.9$ & 55.95 & $20.8,126$ & $<0.001$ \\
\hline Cr clearance (mL/minute) & 86.98 & $24,188.7$ & 48.53 & $13.87,188$ & $<0.001$ \\
\hline Cr clearance (CKD-EPI) & 83.34 & $45.3,138.3$ & 39.04 & $21.3,54.7$ & $<0.001$ \\
\hline \multirow[t]{2}{*}{ Proteinuria (g) } & 0.571 & $0,6.6$ & 1.97 & $0.025,9.62$ & 0.086 \\
\hline & $\mathrm{n}$ & $\%$ & $n$ & $\%$ & \\
\hline No proteinuria $(<300 \mathrm{mg})$ & 79 & 79.79 & 24 & 55.81 & \\
\hline Proteinuria $300 \mathrm{mg}$ to $1 \mathrm{~g}$ & 6 & 6.06 & 8 & 18.60 & \\
\hline Proteinuria $\geq 1 \mathrm{~g}$ & 14 & 14.14 & 11 & 25.58 & \\
\hline $\begin{array}{l}\text { Comorbidities } \\
\text { No diabetes mellitus } \\
\text { Gestational diabetes } \\
\text { DM1 } \\
\text { DM2 } \\
\text { No HBP } \\
\text { Gestational hypertension } \\
\text { HBP } \\
\text { Systemic lupus erythematosus }\end{array}$ & $\begin{array}{c}57 \\
92 \\
1 \\
5 \\
1 \\
55 \\
28 \\
16 \\
5\end{array}$ & $\begin{array}{c}57.57 \\
92.92 \\
1.01 \\
5.05 \\
1.01 \\
55.55 \\
28.28 \\
16.16 \\
5.05\end{array}$ & $\begin{array}{c}24 \\
38 \\
0 \\
5 \\
0 \\
22 \\
5 \\
16 \\
3\end{array}$ & $\begin{array}{c}55.81 \\
88.37 \\
\\
11.62 \\
\\
51.16 \\
11.62 \\
37.20 \\
6.97\end{array}$ & \\
\hline KD diagnosed $<20$ WOG & 23 & 23.23 & 11 & 25.58 & \\
\hline KD diagnosed $>20$ WOG & 47 & 47.47 & 19 & 44.18 & \\
\hline
\end{tabular}

severe depression in $6.33 \%$, and admission to the $\mathrm{NICU}$ in $38.02 \%$ (Table 3).

Newborns overall survival was $86.04 \%$ in the group of children of mothers with moderate KD, and $86.86 \%$ in the children of mothers with mild $\mathrm{KD}$, with a total of four abortions $(4.04 \%)$ in the group of mild KD and one $(2.32 \%)$ in the group with moderate KD. Multivariate logistic regressions were performed for each one of the independent variables regarding perinatal outcome: the presence of anemia (hemoglobin $<11 \mathrm{~g} / \mathrm{dL}$ ) increased 2.92 times the risk of miscarriage $(\mathrm{OR}=2.92,95 \%$ confidence interval $[\mathrm{Cl}]=$
$0.45-18.3, p=0.22$ ), and the presence of KD increased 1.76 times the risk of abortion $(95 \% \mathrm{Cl}=$ 0.19-16.3, $p=0.52$ ) (Table 4).

As for independent variables with statistical significance, uncontrolled blood pressure was observed to increase 93 times the risk of having a premature pregnancy termination $(95 \% \mathrm{Cl}=1.43-33.4, \mathrm{p}=0.0092)$ with regard to ending pregnancy at term, and anemia (hemoglobin $<11 \mathrm{~g} / \mathrm{dL}$ ) increased it 2.48 times (95\% $\mathrm{Cl}=1.21-5.11, \mathrm{p}=0.017$ ); mild and moderate $\mathrm{KD}$ showed a trend towards risk for prematurity of 1.88 times $(95 \% \mathrm{Cl}=0.90-3.90, \mathrm{p}=0.08)$, without 
Table 2. Indications for pregnancy interruption

\begin{tabular}{|c|c|c|c|c|c|c|}
\hline \multirow[t]{2}{*}{ Indications } & \multicolumn{2}{|c|}{ Mild KD } & \multicolumn{2}{|c|}{ Moderate KD } & \multicolumn{2}{|c|}{ Total } \\
\hline & $\mathrm{n}$ & $\%$ & $\mathrm{n}$ & $\%$ & $\mathrm{n}$ & $\%$ \\
\hline $\begin{array}{l}\text { Maternal } \\
\text { Kidney disease } \\
\text { Impaired renal function } \\
\text { Preeclampsia with data consistent with severity } \\
\text { Active phase labor } \\
\text { Labor failure to progress } \\
\text { Cephalopelvic disproportion } \\
\text { Short inter-gestational interval } \\
\text { Twin pregnancy } \\
\text { Breech presentation } \\
\text { Iterative cesarean section } \\
\text { History of uterine surgery } \\
\text { Placenta previa } \\
\text { Oligohydramnios }\end{array}$ & $\begin{array}{l}19 \\
2 \\
33 \\
8 \\
3 \\
3 \\
1 \\
0 \\
2 \\
4 \\
1 \\
4 \\
2\end{array}$ & $\begin{array}{c}19.19 \\
2.02 \\
33.33 \\
8.08 \\
3.03 \\
3.03 \\
1.01 \\
0 \\
2.02 \\
4.04 \\
1.01 \\
4.04 \\
2.02\end{array}$ & $\begin{array}{l}8 \\
7 \\
15 \\
2 \\
0 \\
4 \\
0 \\
1 \\
1 \\
1 \\
0 \\
0 \\
2\end{array}$ & $\begin{array}{c}18.60 \\
16.27 \\
34.84 \\
4.65 \\
0 \\
9.30 \\
0 \\
2.32 \\
2.32 \\
2.32 \\
0 \\
0 \\
4.65\end{array}$ & $\begin{array}{c}27 \\
9 \\
48 \\
10 \\
3 \\
7 \\
1 \\
1 \\
3 \\
5 \\
1 \\
4 \\
4\end{array}$ & $\begin{array}{c}19.01 \\
6.33 \\
33.80 \\
7.04 \\
2.11 \\
4.92 \\
0.70 \\
0.70 \\
2.11 \\
3.52 \\
0.70 \\
2.81 \\
2.81\end{array}$ \\
\hline $\begin{array}{l}\text { Fetal } \\
\text { Abortion } \\
\text { Stillbirth } \\
\text { Low fetal reserve } \\
\text { Intrauterine growth restriction }\end{array}$ & $\begin{array}{l}3 \\
1 \\
8 \\
5\end{array}$ & $\begin{array}{l}3.03 \\
1.01 \\
8.08 \\
5.05\end{array}$ & $\begin{array}{l}1 \\
1 \\
0 \\
0\end{array}$ & $\begin{array}{c}2.32 \\
2.32 \\
0 \\
0\end{array}$ & $\begin{array}{l}4 \\
2 \\
8 \\
5\end{array}$ & $\begin{array}{l}2.81 \\
1.40 \\
5.63 \\
3.52\end{array}$ \\
\hline
\end{tabular}

Table 3. Pregnancy termination route and perinatal outcomes

\begin{tabular}{|c|c|c|c|c|c|c|}
\hline \multirow[t]{2}{*}{ Termination route } & \multicolumn{2}{|c|}{ Mild KD } & \multicolumn{2}{|c|}{ Moderate KD } & \multicolumn{2}{|c|}{ Total } \\
\hline & $\mathrm{n}$ & $\%$ & $\mathrm{n}$ & $\%$ & $\mathrm{n}$ & $\%$ \\
\hline Cesarean section & 82 & 82.82 & 37 & 86.04 & 119 & 83.80 \\
\hline Delivery & 13 & 13.13 & 6 & 13.95 & 19 & 13.38 \\
\hline Curettage & 4 & 4.04 & 0 & 0 & 4 & 2.81 \\
\hline Total & 99 & 100 & 43 & 100 & 142 & 100 \\
\hline Perinatal outcomes & Median & Max-Min & Median & Max-Min & & \\
\hline Weight & 2423.59 & $250-4000$ & 2140.81 & $300-3350$ & & \\
\hline Weeks of gestation & 35.31 & $10-42$ & 34.39 & $21-40$ & & \\
\hline 5-min Apgar & 8.6 & $5-10$ & 8.6 & $5-9$ & & \\
\hline Hospital LOS, days & 9.12 & $0-131$ & 14.88 & $0-83$ & & \\
\hline NICU LOS, days & 3.5 & $0-131$ & 2 & $0-27$ & & \\
\hline
\end{tabular}

$\mathrm{KD}=$ kidney disease $\mathrm{LOS}=$ length of stay; $\mathrm{NICU}=$ neonatal intensive care unit. *Mann-Whitney's U-test.

statistical significance, and proteinuria, 1.4 times (95\% $\mathrm{Cl}=0.66-2.95, \mathrm{p}=0.37$ ).

Anemia was statistically significant (OR $=7.78,95 \%$ $\mathrm{Cl}=1.54-39.16, \mathrm{p}=0.008)$ in showing a decrease in the Apgar score at five minutes, and KD was related 2.99 times to the risk of Apgar indicative of moderate to severe depression $(95 \% \mathrm{Cl}=0.76-11.75, \mathrm{p}=0.130)$.

Blood pressure lack of control increased 3.32 times the risk of IUGR $(95 \% \mathrm{Cl}=0.96-11.40, \mathrm{p}=0.060)$.
Elevated blood pressure levels increased 4.44 times the risk of NICU admission.

\section{Discussion}

Of the patients with a diagnosis of KD and pregnancy, $99(69.72 \%)$ were assigned to the mild KD group, with $99(69.72 \%)$, whereas $43(30.28 \%)$ were included in the moderate KD group, similar to that reported in the 
Table 4. Study variables multivariate analysis with pregnancy outcome in patients with chronic KD

\begin{tabular}{|c|c|c|c|c|c|c|c|c|c|c|}
\hline Variables & $\begin{array}{c}\text { Abortions } \\
n(\%)\end{array}$ & $\begin{array}{l}\text { Births } \\
\text { n (\%) }\end{array}$ & OR & $95 \% \mathrm{Cl}$ & $\mathbf{p}^{*}$ & $\begin{array}{c}\text { Premature } \\
n(\%)\end{array}$ & $\begin{array}{c}\text { Full term } \\
n(\%)\end{array}$ & OR & $95 \% \mathrm{Cl}$ & $p^{*}$ \\
\hline $\begin{array}{l}\text { Chronic kidney disease } \\
\text { Mild } \\
\text { Moderate }\end{array}$ & $\begin{array}{l}4(4.04) \\
1(2.33)\end{array}$ & $\begin{array}{l}95(95.96) \\
42(97.67)\end{array}$ & 1.76 & $0.19-16.3$ & 0.52 & $\begin{array}{l}23(53.5) \\
36(37.9)\end{array}$ & $\begin{array}{l}20(46.5) \\
59(62.1)\end{array}$ & 1.88 & $0.90-3.9$ & $0.0864^{\star *}$ \\
\hline $\begin{array}{l}\text { Proteinuria } \\
\text { Proteinuria } \\
\text { No proteinuria }\end{array}$ & $\begin{array}{c}0(0) \\
5(4.85)\end{array}$ & $\begin{array}{c}39(100) \\
98(95.15)\end{array}$ & - & - & - & $\begin{array}{l}19(48.7) \\
40(40.4)\end{array}$ & $\begin{array}{l}20(51.3) \\
59(59.6)\end{array}$ & 1.4 & $0.66-2.95$ & $0.374^{* *}$ \\
\hline $\begin{array}{l}\text { Blood pressure figures } \\
\text { Normal } \\
\text { Elevated }\end{array}$ & $\begin{array}{l}4(3.08) \\
1(8.33)\end{array}$ & $\begin{array}{c}126(96.92) \\
11(91.67)\end{array}$ & 0.34 & $0.04-3.4$ & 0.361 & $\begin{array}{c}9(81.8) \\
50(39.4)\end{array}$ & $\begin{array}{c}2(18.2) \\
77(60.6)\end{array}$ & 6.93 & $1.43-33.4$ & $0.0092^{* *}$ \\
\hline $\begin{array}{l}\text { Anemia } \\
\text { Anemia } \\
\text { No anemia }\end{array}$ & $\begin{array}{l}3(6.12) \\
2(2.15)\end{array}$ & $\begin{array}{l}46(93.88) \\
91(97.85)\end{array}$ & 2.92 & $0.45-18.38$ & 0.22 & $\begin{array}{l}27(57.4) \\
32(35.2)\end{array}$ & $\begin{array}{l}20(42.6) \\
59(64.8)\end{array}$ & 2.48 & $1.21-5.11$ & $0.017^{* *}$ \\
\hline & $\begin{array}{l}\text { Mod. } \\
\text { and sev. } \\
\text { Depression } \\
n(\%)\end{array}$ & $\begin{array}{c}\text { No } \\
\text { depression } \\
n(\%)\end{array}$ & OR & $95 \% \mathrm{Cl}$ & $p^{*}$ & $\begin{array}{l}\text { IUGR } \\
n(\%)\end{array}$ & $\begin{array}{c}\text { No UIGR } \\
\text { n (\%) }\end{array}$ & OR & $95 \% \mathrm{Cl}$ & $p^{*}$ \\
\hline $\begin{array}{l}\text { Chronic kidney disease } \\
\text { Mild } \\
\text { Moderate }\end{array}$ & $\begin{array}{c}5(11.6) \\
4(4.2)\end{array}$ & $\begin{array}{l}38(88.4) \\
91(95.8)\end{array}$ & 2.99 & $0.76-11.75$ & 0.13 & $\begin{array}{c}5(11.6) \\
23(23.2)\end{array}$ & $\begin{array}{l}38(88.4) \\
76(76.8)\end{array}$ & 0.43 & $0.15-1.23$ & 0.11 \\
\hline $\begin{array}{l}\text { Proteinuria } \\
\text { Proteinuria } \\
\text { No proteinuria }\end{array}$ & $\begin{array}{l}2(5.1) \\
7(7.1)\end{array}$ & $\begin{array}{l}37(94.9) \\
92(92.9)\end{array}$ & 0.71 & $0.14-3.57$ & 1 & $\begin{array}{l}10(25.6) \\
18(17.5)\end{array}$ & $\begin{array}{l}29(74.4) \\
85(82.5)\end{array}$ & 1.62 & $0.67-3.92$ & $0.27^{\star *}$ \\
\hline $\begin{array}{l}\text { Blood pressure figures } \\
\text { Normal } \\
\text { Elevated }\end{array}$ & $\begin{array}{c}0(0) \\
9(7.1)\end{array}$ & $\begin{array}{c}11(100) \\
118(92.9)\end{array}$ & - & - & - & $\begin{array}{c}5(41.7) \\
23(17.7)\end{array}$ & $\begin{array}{c}7(58.3) \\
107(82.3)\end{array}$ & 3.32 & $0.96-11.40$ & 0.06 \\
\hline $\begin{array}{l}\text { Anemia } \\
\text { Anemia } \\
\text { No anemia }\end{array}$ & $\begin{array}{c}7(14.9) \\
2(2.2)\end{array}$ & $\begin{array}{l}40(85.1) \\
89(97.8)\end{array}$ & 7.78 & $1.54-39.16$ & 0.008 & $\begin{array}{c}9(18.4) \\
19(20.4)\end{array}$ & $\begin{array}{l}40(81.6) \\
74(79.6)\end{array}$ & 0.87 & $0.36-2.11$ & 0.76 \\
\hline & $\begin{array}{l}\text { Low birth } \\
\text { weight } \\
\text { n (\%) }\end{array}$ & $\begin{array}{l}\text { Adequate } \\
\text { weight } \\
n(\%)\end{array}$ & OR & $95 \% \mathrm{Cl}$ & $p^{*}$ & $\begin{array}{c}\text { NICU } \\
\text { admission } \\
n(\%)\end{array}$ & $\begin{array}{l}\text { No NICU } \\
\text { admission } \\
n(\%)\end{array}$ & OR & $95 \% \mathrm{Cl}$ & $p^{*}$ \\
\hline $\begin{array}{l}\text { Chronic kidney disease } \\
\text { Mild } \\
\text { Moderate }\end{array}$ & $\begin{array}{l}12(27.9) \\
32(32.3)\end{array}$ & $\begin{array}{l}31(72.1) \\
67(67.7)\end{array}$ & 1.234 & $0.56-2.71$ & $0.6^{\star *}$ & $\begin{array}{c}6(14) \\
17(17.2)\end{array}$ & $\begin{array}{c}37(86) \\
82(82.8)\end{array}$ & 0.78 & $0.28-2.14$ & 0.63 \\
\hline $\begin{array}{l}\text { Proteinuria } \\
\text { Proteinuria } \\
\text { No proteinuria }\end{array}$ & $\begin{array}{l}15(38.5) \\
29(28.2)\end{array}$ & $\begin{array}{l}24(61.5) \\
74(71.8)\end{array}$ & 1.595 & $0.73-3.46$ & $0.23^{\text {** }}$ & $\begin{array}{c}7(17.9) \\
16(15.5)\end{array}$ & $\begin{array}{l}32(82.1) \\
87(84.5)\end{array}$ & 1.18 & $0.44-3.15$ & 0.72 \\
\hline $\begin{array}{l}\text { Blood pressure figures } \\
\text { Normal } \\
\text { Elevated }\end{array}$ & $\begin{array}{l}5(41.7) \\
39(30)\end{array}$ & $\begin{array}{l}7(58.3) \\
91(70)\end{array}$ & 1.66 & $0.49-5.57$ & 0.4 & $\begin{array}{c}5(41.7) \\
18(13.8)\end{array}$ & $\begin{array}{c}7(58.3) \\
112(86.2)\end{array}$ & 4.44 & $1.27-15.52$ & 0.012 \\
\hline $\begin{array}{l}\text { Anemia } \\
\text { Anemia } \\
\text { No anemia }\end{array}$ & $\begin{array}{l}16(32.7) \\
28(30.1)\end{array}$ & $\begin{array}{l}33(67.3) \\
65(69.9)\end{array}$ & 1.12 & $0.53-2.36$ & $0.75^{\star *}$ & $\begin{array}{c}9(18.4) \\
14(15.1)\end{array}$ & $\begin{array}{l}40(81.6) \\
79(84.9)\end{array}$ & 1.26 & $0.50-3.1$ & 0.61 \\
\hline
\end{tabular}

${ }^{*}$ Fisher's exact test; ${ }^{* *}$ Chi-square test.

$\mathrm{OR}=$ odds ratio; $\mathrm{Cl}=$ confidence interval; $\mathrm{NICU}=$ neonatal intensive care unit; IUGR = intrauterine growth restriction

literature, where the largest proportion of patients is referred to have mild KD during pregnancy.

Birth weight recorded in the children of mothers with mild KD was $2423 \mathrm{~g}(250-4000 \mathrm{~g})$, whereas that of the children of mothers with moderate KD was $2140 \mathrm{~g}$ (300-3350 g), with a difference of $283 \mathrm{~g}$ between both groups' median weight, which was not statistically significant with a p-value of 0.177 using 
Mann-Whitney's U-test. In the group of women with mild KD, there were $63.63 \%$ of newborns with adequate weight for gestational age, $32.32 \%$ with low weight for gestational age and $1.01 \%$ with high weight for gestational age. In the group of women with moderate $\mathrm{KD}, 72.09 \%$ of newborns were recorded to have adequate weight for gestational age and $27.90 \%$ had low weight.

In both groups, $19.71 \%$ of IUGR was recorded; in the group with mild $K D$ it was $23.23 \%$, and in the group with moderate $\mathrm{KD}$ it was $11.62 \%$, a proportion slightly higher than that reported by Trevisan et al., who indicated $13 \%$, and lower to that reported by Jones and Hayslett, who referred $37 \%$ of IUGR, and by Cunningham, who reported $35 \%$.

Gestational age difference at birth was statistically significant between both groups: in women with mild $\mathrm{KD}$, the median was 35.31 weeks, while in women with moderate $K D$, it was 34.39 weeks, with a p-value of 0.023 . In women with mild KD, $59.59 \%$ of full-term pregnancies were identified; there were $32.32 \%$ of premature newborns of between 28.1 and 36.6 weeks of gestation, and $4.04 \%$ were extremely premature. In the group with moderate $\mathrm{KD}$, there were $46.51 \%$ of full-term pregnancies, $44.18 \%$ of premature newborns of between 28.1 and 36.6 weeks of gestation, and $9.30 \%$ were extremely premature. In both groups, $55.63 \%$ of full-term pregnancies and $44.37 \%$ of premature deliveries were found. In general, preterm neonates were fewer than those reported by Trevisan et al., who indicate $60 \%$ of premature newborns, while Jones and Hayslett report 59\%. However, they were more than those reported by Cunningham (30\%).

Differences in the days of hospital length of stay (LOS) and days of NICU LOS were not statistically significant between both groups, with a p-value of 0.681 for the days of hospital LOS and of 0.910 for the days of NICU LOS. In the group with moderate $\mathrm{KD}, 86.04 \%$ of newborns were admitted to the NICU, while in the group with mild KD only $17.17 \%$ were admitted.

Five-minute Apgar score was 7 to 10 (no depression) in $90.90 \%$ of the children of mothers with mild $\mathrm{KD}$ and in $88.37 \%$ of the children of mothers with moderate KD; $4.04 \%$ of the children of mothers with mild KD showed moderate depression (4 to 6 Apgar score) in comparison with $2.32 \%$ of the children of mothers with moderate KD. Severe depression (Apgar $\leq 3$ ) was recorded in $5.05 \%$ of the children of mothers with mild KD and in $9.30 \%$ of the children of mothers with moderate $\mathrm{KD}$.
Overall survival of the neonates was $86.61 \%$ for both groups, $86.04 \%$ in the group of children of mothers with moderate $\mathrm{KD}$, and $86.86 \%$ in the children of mothers with mild RD, which is slightly lower than the 93\% rate reported by Jones and Hayslett and slightly higher than the $82 \%$ rate referred by Jungers et al. after excluding first trimester abortions (which were taken into account in our study). In the group of women with mild $\mathrm{KD}$, abortion was recorded in $4.04 \%$, and regarding their children, intrauterine death in $1.01 \%$, early neonatal death in $6.06 \%$ and late neonatal death in $2.02 \%$; in the group of women with moderate $\mathrm{KD}$, abortion was recorded in $2.32 \%$, intrauterine death in $6.97 \%$, early neonatal death in $2.32 \%$ and late neonatal death in $2.32 \%$.

Blood pressure figures lack of control $(p=0.0092)$ and hemoglobin $<11 \mathrm{~g} / \mathrm{dL}(p=0.017)$ showed a statistically significant relationship with premature birth. Apgar < 3, which indicates moderate and severe depression, was statistically significant with hemoglobin levels $<11 \mathrm{~g} / \mathrm{dL}(p=0.008)$.

NICU admission had a statistically significant relationship with uncontrolled blood pressure figures $(p=0.012)$. Low birth weight, IUGR, abortion, intrauterine death and neonatal death showed no statistically significant relationships with the degree of KD (mild and moderate), proteinuria, hemoglobin levels and blood pressure figures. Unlike the findings reported by Zhang et al., who refer that uncontrolled hypertension and proteinuria worsen fetal outcomes, in this study, a statistically significant relationship was only found between uncontrolled blood pressure levels and the birth of premature children and NICU admission. Proteinuria had no statistically significant relationship with perinatal morbidity and mortality results; however, taking these results with caution is advised, since they differ from those reported in the literature and could be caused by inadequate 24 -hour urine collection.

Hemoglobin levels $<11 \mathrm{~g} / \mathrm{dL}$ had a statistically significant relationship with Apgar scores $<3$ and with the birth of premature children. This has not been reported in the literature, since, in most studies, maternal hemoglobin is evaluated in patients with severe $\mathrm{KD}$ during pregnancy and it is not reported in patients with mild and moderate KD.

\section{Conclusions}

Average age in both groups was 29 years; the KD cause was unknown in $48.48 \%$ of women with mild and 
in $76.74 \%$ with moderate disease; the main indication for pregnancy termination was preeclampsia with data consistent with severity, and the second, chronic KD. Average gestational age at birth was 35.31 and 34.39 weeks and birth weight was 2423 and $2140 \mathrm{~g}$ in the children of women with mild and moderate $\mathrm{KD}$, respectively. Unlike observations reported in the literature, no statistically significant relationship was found between proteinuria and perinatal adverse outcomes; however, anemia and elevated blood pressure figures were statistically significantly associated with prematurity, low Apgar score and NICU admission.

Based on our findings, we believe that prospective studies should be conducted, and follow-up of the mother and the child before, during and after pregnancy should be carried out in a protocol-based and multidisciplinary manner in order for perinatal results to be improved.

\section{Conflict of interests}

The authors declare that they have no conflicts of interest.

\section{Funding}

The authors did not receive any sponsoring to carry out this article.

\section{Ethical disclosures}

Protection of human and animal subjects. The authors declare that no experiments were performed on humans or animals for this research.

Confidentiality of data. The authors declare that they have followed the protocols of their work center on the publication of patient data.

Right to privacy and informed consent. The authors declare that no patient data appear in this article.

\section{References}

1. Fischer MJ, Lehnerz SD, Hebert JR, Parikh CR. Kidney disease is an independent risk factor for adverse fetal and maternal. Am J Kidney Dis. 2004;43:415-23

2. Manterola D, Hernández JA, Estrada A. Enfermedad renal crónica durante el embarazo: curso clínico y resultados perinatales en el instituto nacional de perinatología isidro espinosa de los reyes. Perinatol Reprod Hum. 2012;26:147-53.

3. Podymow T, August $\mathrm{P}$, Akbari A. Management of renal disease in pregnancy. Obstet Gynecol Clin North Am. 2010;37:195-210.

4. Davison JM, Lindheimer MD. Pregnancy and chronic kidney disease. Semin Nephrol. 2011;31:86-99.

5. Davison JM, Lindheimer MD. Renal disorders. In: Creasy RK, Resnik R, lams JD, editors. Maternal-fetal Medicine Principles and Practice. United States: Saunders; 2004.

6. Hayslett JP. Interaction of renal disease and pregnancy. Kidney Int 1984:25:579-87.

7. Hernández-Rivera JC, Pérez-López MJ, Corzo-Bermúdez $\mathrm{CH}$, García-Covarrubias L, Bermúdez-Aceves L, Chucuan-Castillo CA, et al. Delayed initiation of hemodialysis in pregnant women with chronic kidney disease: logistical problems impact clinical outcomes. An experience from an emerging country. J Clin Med. 2019;8:475.

8. Ramin SM, Vidaeff AC, Yeomans ER, Gilstrap LC. Chronic renal disease in pregnancy. Obstet Gynecol. 2006;108:1531-8.

9. Trevisan G, Lopes-Ramos JG, Martins-Costa S, Barros EJ. Pregnancy in patients with chronic renal insufficiency at Hospital de Clínicas of Porto Alegre, Brazil. Ren Fail. 2004;26:29-34.

10. Jones DC, Hayslett JP. Outcome of pregnancy in women with moderate or severe renal insufficiency. N Engl J Med. 1996;335:226-332.

11. Holley JL, Bernardini J, Quadri KH, Greenberg A, Laifer SA. Pregnancy outcomes in a prospective matched control study of pregnancy and renal disease. Clin Nephrol. 1996;45:77-82.

12. Jungers $P$, Chauveau D. Pregnancy in renal disease. Kidney Int. 1997;52:871-85.

13. Nevis IF, Reitsma A, Dominic A, McDonald S, Thabane L, Akl EA, et al. Pregnancy outcomes in women with chronic kidney disease: a systematic review. Clin J Am Soc Nephrol. 2011;6:2587-98.

14. Cunningham FG, Cox SM, Harstad TW, Mason RA, Pritchard JA. Chronic renal disease and pregnancy outcome. Am J Obstet Gynecol. 1990;163:453-9.

15. Zhang JJ, Ma XX, Hao L, Liu LJ, Lv JC, Zhang H. A systematic review and meta-analysis of outcomes of pregnancy in CKD and CKD outcomes in pregnancy. Clin J Am Soc Nephrol. 2015;10:1964-78.

16. Luders C, Castro MC, Titan SM, de Castro I, Elias RM, Abensur H, et al. Obstetric outcome in pregnant women on long-term dialysis: a case series. Am J Kidney Dis. 2010;56:77-85.

17. Hladunewich MA, Melamad N, Bramham K. Pregnancy across the spectrum of chronic kidney disease. Kidney Int. 2016;89:995-1007.

18. Lindheimer MD, Katz Al. Gestation in women with kidney disease: prognosis and management. Baillieres Clin Obstet Gynaecol. 1994:8:387-404.

19. Munkhaugen J, Lyndersen S, Romundstad PR, Wideroe TE, Vikse BE, Hallan S. Kidney function and future risk for adverse pregnancy outcomes: a population-based study from HUNT II, Norway. Nephrol Dial Transplant. 2009;24:3744-50

20. Hou SH, Grossman SD, Madias NE. Pregnancy in women with renal disease and moderate renal insufficiency. Am J Med. 1985;78:185-94.

21. Katz Al, Davidson JM, Hayslett JP, Singson E, Lindheimer MD. Pregnancy in women with kidney disease. Kidney Int. 1980;18:192-206.

22. Epidis K. Pregnancy in women with renal disease. Yes or no? Hippokratia. 2011;15:8-12

23. Guzmán-Solís M, Sánchez-Rodríguez $O$, Montaño-Martínez $A$, Peredo-Villa D, Paniagua-Sierra R, Trejo-Villeda M, et al. Desenlaces obstétricos en mujeres embarazadas con enfermedad renal crónica y factores asociados. Ginecol Obstet Mex. 2020;88:230-43. 
Appendix 1. Classification of kidney disease during pregnancy.

\section{Davison-Lindheimer classification}

Mild kidney disease

Serum creatinine $<1.4 \mathrm{mg} / \mathrm{dL}$

Moderate kidney disease

Serum creatinine $>1.4 \mathrm{mg} / \mathrm{dL}-<2.8 \mathrm{mg} / \mathrm{dL}$

Severe kidney disease

Serum creatinine $>2.8 \mathrm{mg} / \mathrm{dL}$

Appendix 2. Jurado-García graph. Correlation of birth weight with gestational age.

BIRTH WEIGHT IN RELATION TO GESTATIONAL AGE BOTH GENDERS

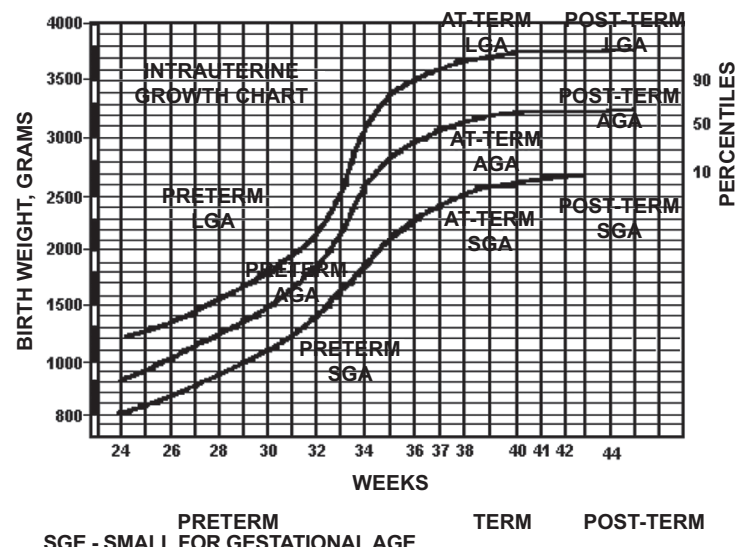

SGE - APPROPRIATE FOR GESTATIONAL AGE Dr. Jurado García

LGE - LARGE FOR GESTATIONAL AGE 